MADROÑO, Vol. 59, No. 4, p. 234, 2012

\title{
PRESIDENT'S REPORT FOR VOLUME 59
}

Dear CBS member,

This year, 2012, has been a transitional year for the Society. We passed our 99th birthday as a Society on April 13, 2012. To celebrate our Centennial in April 2013, we are organizing a symposium in Berkeley, California, with invited speakers and a special banquet, in conjunction with the 23 rd graduate student meetings. We have also planned, and have conducted, a series of field trips in honor of the 100th birthday. Please see www.calbotsoc.org for all the information on the Centennial.

This year we signed an agreement with JSTOR (an online archiving system) to place all of our Madroño back issues online. Current issues are already online through BioOne.2. We are moving toward having the current online issues easily available to members, so look forward to that. One of the journal's editors, Richard Whitkus, has announced that he is stepping down after several critical years. We all are thankful to have had Rich during the time the journal converted to an online manuscript submission and tracking process and rapidly caught back up on schedule.

For 2012, we did not hold a separate banquet meeting, but instead sponsored the banquet speaker for the California Native Plant Society's January Conservation Conference in San Diego. Peter Raven, Director Emeritus of the Missouri Botanical Garden, was our invited speaker, and he gave a wonderful talk reflecting on the history of Western North American botany and what the future may hold.

The Council has worked particularly hard for you this year and I would especially like to thank Andrew Doran, Dean Kelch, Kim Kersh, Staci Markos, Anna Larsen, Matt Ritter, Tom Schweich, Ellen Simms, Michael Vasey, and Rich Whitkus. All of our Council members have been critically important this year. We also welcome Genevieve Walden from UC Berkeley as the new graduate student representative; Genevieve will be organizing the 2013 graduate student meetings.
Reaching 100 years as a Society has moved the Council into a reconsideration of the role of the California Botanical Society. The founding goals of supporting botanical research and communicating that broadly have been largely achieved, but California and western North America are no longer characterized by low populations and difficult travel. Journeying across our mountain ranges may take some time, but we no longer consider them expeditions. Electronic communication has rapidly changed the way scientists communicate and we are transitioning as fast as we can afford. Because our membership base is the foundation of the Society, we would like to hear from you about what roles you see for the Society in the future. Please contact any of the Council members and let us hear from you. Of course, increasing our membership is always a priority, so please continue to encourage your colleagues to join us and to publish in Madroño. This is especially true of our younger colleagues. Moving online should make us more attractive to the younger cohorts of botanists more accustomed to this format.

Lastly, I regret to note the passing of Dr. John O. Sawyer (1939-2012) for whom our 2008 volume of Madrono was dedicated. John was a stellar plant ecologist who joined the faculty at Humboldt State University in 1966 and remained there until he retired. He mentored many graduate students who are now professional botanists, was a president of the CNPS and founder of its North Coast Chapter, and was instrumental in preparing two editions of the Manual of California Vegetation. His humor, deep passion for and knowledge of the vegetation of northwestern California will be sorely missed.

V. Thomas Parker December 2012 


\section{$2 \mathrm{BHL}$ Biodiversity Heritage Library}

Parker, V Thomas. 2012. "President's Report for Volume 59." Madroño; a West American journal of botany 59, 234-234.

https://doi.org/10.3120/0024-9637-59.4.234.

View This Item Online: https://www.biodiversitylibrary.org/item/185599

DOI: https://doi.org/10.3120/0024-9637-59.4.234

Permalink: https://www.biodiversitylibrary.org/partpdf/169175

\section{Holding Institution}

Smithsonian Libraries

\section{Sponsored by}

Biodiversity Heritage Library

\section{Copyright \& Reuse}

Copyright Status: In Copyright. Digitized with the permission of the rights holder License: http://creativecommons.org/licenses/by-nc/3.0/ Rights: https://www.biodiversitylibrary.org/permissions/

This document was created from content at the Biodiversity Heritage Library, the world's largest open access digital library for biodiversity literature and archives. Visit BHL at https://www.biodiversitylibrary.org. 